\title{
THE RELATIONSHIPS BETWEEN CHARACTER STRENGTHS AND LIFE FULFILLMENT IN THE VIEW OF LAY-PEOPLE IN ARGENTINA*
}

\author{
ALEJANDRO CASTRO SOLANO** AND ALEJANDRO CÉSAR COSENTINO***
}

\author{
${ }^{*}$ This research was supported in part by Grant 20020120200076 of the Universidad de Buenos Aires (UBA). \\ ${ }^{* *} \mathrm{PhD}$ in Psychology. Researcher of Consejo Nacional de Investigaciones Científicas y Técnicas (CONICET). \\ E-Mail: alejandro.castrosolano@gmail.com \\ Paraguay 5337, 5th floor "A", (1425) Buenos Aires, República Argentina. \\ ${ }^{* * * P h D}$ in Psychology. Professor Department of Psychology, Faculty of Social Sciences, Universidad de Palermo (UP).
}

\section{RESUMEN}

Se examinó la importancia de las fortalezas del carácter para el desarrollo positivo desde el punto de vista de las personas legas. Una muestra de 687 adultos evaluó la importancia de las 24 fortalezas del carácter de la clasificación $\mathrm{Va}$ lues in Action para cinco áreas: bienestar personal, metas personales, relaciones personales y laborales y contribuir a un país mejor. Se diseñó un instrumento basado en la metodología de la encuesta que estaba compuesto por 24 ítems. Cada uno evaluaba una fortaleza en cada una de las cinco áreas comentadas. La confiabilidad global del mismo fue igual a .98. Los datos se analizaron mediante la inspección de las frecuencias (por ej.: grado de respaldo a cada una de las fortalezas en relación con el desarrollo positivo), considerando aquellas fortalezas que se encontraban por encima del percentil 90. En general, los resultados han mostrado que la fortaleza del carácter honestidad es un importante recurso personal para las cinco áreas consideradas en este estudio. Específicamente, amor, honestidad y vitalidad son las fortalezas del carácter más importantes para el bienestar personal; perseverancia y autorregulación, para lograr metas vitales, honestidad y gratitud para el desarrollo de relaciones positivas; compañerismo e imparcialidad para las relaciones laborales positivas, e imparcialidad y honestidad para contribuir a un país mejor. Se analizaron las diferencias por gé- nero y edad y se encontró que las mujeres consideraban a las fortalezas mucho más importantes que los varones para la mayoría de las áreas vitales consideradas. Este estudio señala que las concepciones implícitas de las personas legas deberían ser tomadas en cuenta a la hora de diseñar estrategias de intervención positivas basadas en las fortalezas del carácter.

Palabras clave: Psicología Positiva; Valores; Personas legas; Fortaleza del carácter; Desarrollo positivo.

\section{ABSTRACT}

The idea underlying this work is that character strengths are an essential component for achieving life fulfillment. In order to determine the extent to which strengths of character are essential to living a good life, this study was conducted from laypeople's point of view. This work took as theoretical framework Seligman's recent theory, known under the acronym of PERMA, which proposes that human strengths are vehicles for achieving positive emotions, engagement (flow), enriching relationships, meaning in life, and accomplishment of personal goals. This study considered life fulfillment beyond the hedonic conception of subjective well-being emphasizing the importance of both individual and social meaning; the relationship with others; and the achieve- 
ment of personal goals, among others. A sample of 687 adults evaluated the importance of 24 character strengths from the Values in Action classification for the five areas that contribute to a fulfilling life: personal well-being, personal goals, personal relationships, work relationships, and contributing to a better country. This study used a similar methodology to Biswas-Diener (2006), who studied the attitudes towards the 24 VIA character strengths with members of dissimilar cultural groups. An instrument was designed comprising 24 items in a survey-format. Each item assessed one character strength for each of the five areas under study. Cronbach's alpha reliability test for the overall scale was .98. Data was analyzed by calculating frequencies (e.g., the degree of endorsement to the character strengths in relation to life fulfillment) and conducting chi-square tests (e.g., gender and age differences). The character strengths over the 90th percentile were considered. The results showed that the character strength honesty is an important personal resource for the five areas studied. Specifically, love, honesty and zest were the major character strengths for personal well-being; persistence and self-regulation for achieving life goals; honesty and gratitude for developing positive personal relationships; citizenship and fairness for positive work relationships; and, fairness and honesty for contributing to a better country. Differences by gender were found. For the majority of the areas of life explored, women placed more importance on character strengths than men. The main finding of this study is that people consider the strengths of character from the VIA classification as important elements for life fulfillment. Most participants in this study showed a high degree of endorsement (60 to 70\%) to each of the character strengths of the VIA classification for all the areas, i.e., achieving personal well-being, accomplishing life goals, enriching personal relationships, working well with others, and contributing to a better country. Based on these results, it can be concluded that from the point of view of lay-people, character strengths are not only fundamental to feel good but also to function well both in relation to themselves and to the world. Overall, intervention strategies, from the Positive Psychology perspective, tend to be generic and unspecific, without considering individuals' particular points of view. Knowing people's implicit ideas in relation to the strengths that contribute most to life fulfillment would allow generating more accurate and culturally adjusted interventions to the particular group in question. This adjustment not only operates as a key motivational aspect but also a reinforcement of the effect of the intervention. Future studies should experimentally compare the effectiveness of generic interventions on character strengths versus interventions focused on those strengths that the group under study deems important, especially in Latino populations in which the efficacy of these interventions has not been tested yet, and little has been studied in relation to this topic.

Key words: Positive Psychology; Values; Laypeople; Character strengths; Flourishing.

What are the positive traits that make us feel good? What character strengths make us work satisfactorily? What features do we need to cultivate as citizens to have a prosperous nation? Having these questions in mind a research study was designed using Peterson and Seligman's (2004) classification of the virtues and strengths of character as a theoretical framework. The idea underlying this work is that character strengths are an essential component for well-being (Seligman, 2011). In order to determine the extent to which strengths of character are essential to living a good life, this study was conducted from laypeople's point of view. This intersection between character strengths and well-being is also present in Seligman's recent theory of wellbeing, known under the acronym of PERMA, which proposes that human strengths are vehicles for achieving positive emotions, engagement (flow), enriching relationships, meaning in life, and accomplishment of personal goals (Forgeard, Jayawickreme, Kern, \& Seligman, 2011; Seligman, 2011).

Peterson and Seligman (2004) proposed a scientific methodology for the study of positive traits and a classification of character strengths and virtues that is currently used by researchers worldwide. They believed that 
establishing a classification of character was a necessary step towards the scientific study of moral excellence. These researchers developed a classification of core virtues to be used both as a basis for empirical study and as a foundation for developing interventions. To accomplish these objectives, Peterson and Seligman surveyed various definitions of morally good behavior based on the most influential philosophical and religious traditions of human civilization. It was found that six fundamental virtues were repeated in these traditions: courage, justice, humanity, temperance, wisdom, and transcendence (Dahlsgaard, Peterson, \& Seligman, 2005). Afterward, a group of academics proposed a tentative list of character strengths to include in the classification. The list was refined through a series of debates, resulting in 24 character strengths classified into the 6 virtues (refer to Table 1). The classification, called Values in Actions (VIA), was created as a positive alternative to the Diagnostic and Statistical Manual of Mental Disorders (DSM - American Psychiatric Association, 2013). This classification aimed to develop a common language for Positive Psychology research.

Since then, Peterson and Seligman's (2004) classification of character strengths and virtues, together with the study of well-being, were the cornerstones of the Positive Psychology movement, which has achieved remarkable growth in the past 15 years both in scientific research and application (Castro Solano, 2014). Several studies have reported a positive association between character traits and other positive psychological outcomes such as school success, prosocial behavior, and competence in youth (Park, 2004, for a review). Other variables of interest related to character strengths are age and sex (Linley et al., 2007); genetics (Steger, Hicks, Kashdan, Krueger, \& Bouchard, 2007); life satisfaction (Park, Peterson, \& Seligman, 2004); personality (Mac Donald, Bore, \& Munro, 2008); academic performance among university students (Lounsbury, Fisher, Levy, \& Welsh, 2009); military and academic performance among military students (Cosentino \& Castro Solano, 2012); health recovery (Peterson, Park \& Seligman, 2006); and post- traumatic growth (Peterson, Park, Pole, D'Andrea, \& Seligman, 2008), among others.

Additionally, it has been proposed that the character strengths, as classified by the VIA, are universal (Dahlsgaard et al., 2005; Park et al., 2006). In essence, in diverse types of populations - university students in the United States (US) and remote cultures such as the Maasai in Kenya and the Inughuit in Northern Greenland - it was found high rates of agreement on the existence, importance and desirability (e.g., wanting their child to have each virtue) of the strengths of character (BiswasDiener, 2006). Moreover, it was observed that character strengths are remarkably similar across 54 nations and across different regions of the US (Park et al., 2006).

Empirical studies on character strengths show a positive association between the strengths of character and satisfaction with life. According to a large cross sectional study conducted by Park, Peterson, \& Seligman (2004), with almost 4000 participants, the five character strengths most highly related to life satisfaction were hope, zest, gratitude, curiosity and love. In another study, Ruch, Huber, Beermann, and Proyer (2007) showed that all 24 strengths were positively correlated with life satisfaction. In addition to the connection between hope, gratitude, love and zest to satisfaction with life, hope and spirituality were the best predictors of future life satisfaction (Proyer, Gander, Wyss, \& Ruch, 2011). Among youth, the character strengths most closely related to life satisfaction were love, hope, and zest. Particularly, parents who described their young children (ages 3 to 9) as happy also described them as showing love, hope, and zest (Park \& Peterson, 2009). In a recent study, transcendence strengths (e.g., gratitude, hope, and spirituality) were the stronger predictors of achieving a satisfying life and displaying positive affect (Weber, Ruch, Littman-Ovadia, Lavy, \& Gai, 2013). In the same vein, an experimental research that tested the character strengths more strongly related to life satisfaction (e.g., hope, zest, gratitude, curiosity and humor) demonstrated that the participants assigned to the experimental group targeting those strengths showed the strongest improv- 
ement in life satisfaction (Proyer et al., 2013). So far, the literature reveals a relationship between character strengths and the hedonic conception of well-being (e.g. life satisfaction). However, research have not yet examined the association between character strengths, according to the VIA classification, and the eudaimonic perspective of well-being (e.g. life fulfillment).

Therefore, the present study aims to examine the extent to which people believe that character strengths are important in achieving a fulfilling life. Life fulfillment, as the conceptualization of well-being within a eudaimonic point of view, includes various components drawn from diverse theories and models (Huta \& Ryan, 2010; Huta \& Waterman, 2014). For instance, the concepts of psychological well-being (Ryff, 1989) which comprehends autonomy, positive relations, environmental mastery, self-acceptance, purpose in life and personal growth; eudaimonic wellbeing (Waterman, 2008), that focuses on selfexpressiveness, development of inner potentials, and self-actualization; and, the SelfDetermination Theory (Ryan \& Deci, 2000) that is based on the psychological needs for competence, autonomy, and relatedness; as well as other models centered on the perception of meaning in life (Baumeister, Vohs, Aaker, \& Garbinsky, 2013; King \& Hicks, 2009; Steger, Frazier, Oishi, \& Kaler, 2006; Wong, 2011). In other words, a fulfilling life goes beyond the hedonic conception of subjective well-being and emphasizes the importance of both individual and social meaning, of the relationship with others and the achievement of personal goals (Seligman, 2011; Keyes, 2002, 2007; Ryff, 1989, 2014).

In Seligman's (2002) first theory, known as authentic happiness, he proposed three essential pillars of well-being: pleasure, engagement and meaning. The first pillar explores subjective experiences that are positively valued, such as positive emotions, life satisfaction and subjective well-being (Diener, Emmons, Larsen, \& Griffin, 1985; Pavot \& Diener, 2008). This pillar reflects the development of hedonic theories of well-being. According to Seligman, the second pillar com- prises the study of engagement, involvement and absorption in work, intimate relations and leisure, a psychological state that has been named as flow (Csíkszentmihályi, 1990). The strengths of character have been found to play a central role for reaching the state of flow (Seligman, 2002). Thus, acknowledging ones' signature strengths and finding contextual opportunities to use them more are a unique way to achieve engagement: Individual's subjective well-being results from enhancing and using one's character strengths (Park, 2004). Seligman (2002) described the third pillar as related to positive institutions and the pursuit of meaning, that is, belonging to and serving something that is bigger than the self (Seligman, Rashid, \& Parks, 2006).

In a most recent work, Seligman's (2011) developed a theory of well-being, named PERMA, that adds two more elements, relationships and accomplishment, to the previous concepts of pleasure, engagement, and meaning (Forgeard et al., 2011). In this PERMA model, Seligman posits that is well-being, and not happiness the main topic of Positive Psychology and considers it as a construct that can be assessed by self-report measures. While in his previous theory (authentic happiness) the life satisfaction was the center of attention and strengths and virtues were only the support for the second pillar (engagement); in the wellbeing theory (PERMA), the twenty-four character strengths are viewed as key elements in achieving well-being and underpin all five elements of the theory and not just engagement. According to Seligman (2011), displaying the signature strengths leads to more positive emotion, to more meaning, to more accomplishment, and to better relationships. In sum, according to these conceptualizations, character strengths allow people to experience a fulfilling life.

Inspired by Seligman's recent work, where character strengths play a key role in achieving well-being, and using a similar methodology to Biswas-Diener (2006), who studied the attitudes towards the 24 VIA character strengths with members of dissimilar cultural groups, the present study investigated from lay-people's point of view, the extent to which 
character strengths are important in relation to five key areas that contribute to life fulfillment: subjective well-being, life goals, relationships with others (personal and work), and with society as a whole. The hypotheses of this study were that character strengths were positively associated to life fulfillment, and that there were differences in frequencies between gender and age groups.

\section{METHOD}

\section{Research design and Participants}

This research was a descriptive and correlational cross-sectional study.

The participants of this study included a convenience sample of 687 adult residents in the City of Buenos Aires, 349 men (51\%) and 338 women (49\%). The mean age of participants was 39.34 years $(S D=15.07)$. The sample was balanced by gender and age. Regarding the highest education level achieved, $60 \%(n=412)$ of participants reached a tertiary education and $40 \%(n=275)$ had completed high school. That means it was a highly educated sample. Regarding marital status, $28 \%(n=192)$ of participants were single and $72 \%(n=495)$ were in a relationship. In regards to socioeconomic status (SES), the sample was divided into: .6\% low SES; $6.3 \%$ lower-middle SES; $67.2 \%$ middle SES; $24.4 \%$ upper-middle SES; and $1.6 \%$ high SES. Participation was voluntary, anonymous, and that there was no obligation to participate or to continue participating. No contribution was given in exchange. Participants were recruited by Psychology undergraduate students from a university at Buenos Aires City, as part of their credits to approve their courses.

\section{INSTRUMENT}

Respondents answered a series of items developed by the authors that linked each of the 24 character strengths with the five aspects of life fulfillment. Each item was worded first with the name of the character strength (e.g., gratitude), followed by a brief description to ensure proper and uniform understanding among participants. A sample item is, Gratitude: feeling and expressing gratefulness. The participants evaluated the importance of each character strength to (a) reaching personal well-being; (b) accomplishing life goals; (c) enriching relationships with others; (d) working well with others; and (e) contributing to a better country. The participants responded with a 6-item Likert scale, with 1 signifying extremely insignificant and 6 signifying extremely significant. The instrument has a paper-and-pencil format. Cronbach alpha for the overall scale was .98. For this particular sample, high Cronbach's alpha coefficients were observed for the five areas of life fulfillment: personal well-being $(\alpha=.91)$; life goals $(\alpha=.91)$; relationships $(\alpha=.91)$; working with others $(\alpha=.92)$; and contributing to a better country $(\alpha=.93)$. A similar methodology used by Biswas-Diener (2006) was followed in order to establish the importance, existence, and presence of each character strength in different cultural groups.

\section{PROCEDURE}

The strategy for data analysis was first to conduct frequency analyses (i.e., the endorsement to the character strengths in relation to life fulfillment) and next, to run chisquare test in order to compare differences in frequencies between groups. The degree of endorsement to the character strengths was analyzed for each of the five areas discussed (personal well-being, personal goals, personal and work relationships, and contributing to a better country). A character strength was classified as important if it was described by the participant as very important or extremely important (scores 5 and 6 on the scale). Consistently, endorsement to each human strength was divided into two categories: high support (scores 5 and 6) and low support (scores 1 to 4). Next, high percentages of support for each character 
strength were listed in descending order (see Table 1) and for each area of a fulfilling life, the first quartile (percentile $>75$ ) and the first decile (percentile $>90$ ) were determined. Regarding the analysis of individual differences by gender and age, only strengths of character located in the first quartile (percentile $>75$ ) were considered.

\section{RESULTS}

CHARACTER STRENGTHS FOR REACHING PERSONAL WELL-BEING

The analysis of the results indicates that the major strengths of character for the development of personal well-being are love, honesty and zest (90th percentile $=84.50)$. This result is representative of the high degree of agreement among the participants that having close relationships with people they are emotionally attached to and being sensitive to their needs; being consistent with their own values; and having integrity in conduct constitute the positive traits to feeling well. Zest, in essence, is a subjective experience at both a physical and psychological level.

Other character strengths viewed as important by participants included hope, humor, gratitude and kindness ( 75 th percentile = 78.30). This means that having a positive mood and optimistic vision for the future, being grateful to others, as well as helping behavior without utilitarian motives, were the character strengths considered important for the development of personal well-being.

In a second step, the existence of individual differences based on gender and age were verified. Differences were found by gender, in which women compared to men emphasized the importance of the character strengths of love $\left(90.8 \%\right.$ vs $85.4 \%, \chi^{2}=4.80$, $p<.05)$, hope $\left(85.5 \%\right.$ vs $79.9 \%, \chi^{2}=3.70$, $p<.05)$, gratitude $\left(82 \%\right.$ vs $74.8 \%, \chi^{2}=5.19$, $p<.05)$, and kindness (84\% vs $72.8 \%$, $\left.\chi^{2}=12.78, p<.01\right)$. This result indicates that women, more than men, emphasize the importance of close emotional ties, an optimistic vision of the future, as well as grate- fulness and solidarity with others as character strengths for achieving well-being. In terms of differences by age, younger individuals placed a greater importance on humor compared to older individuals $(H=$ Kruskal $16.41, p<.01)$. Younger participants felt that having a happy and serene view of life was more important for personal well-being.

\section{CHARACTER STRENGTHS FOR ACCOMPLISHING LIFE GOALS}

The analysis of the results indicates that the major character strengths for achieving life goals are persistence and self-regulation (90th percentile $=77.50)$. This result indicates that the strengths of character contributing to personal achievement include the ability to persevere despite obstacles and the capability to regulate ones' responses to stimuli in order to adapt and to meet certain social standards.

Other character strengths that were also important among participants were zest, hope, prudence, and honesty (75th percentile $=70.67)$. This result indicates that the subjective experience of feeling alive and effective, an optimistic vision of the future, making decisions carefully, and congruence between values and behaviors were the strengths of character that promoted achievement of life goals.

In a second step, individual differences by gender and age were studied. Differences were found by gender, in which women, compared to men, placed greater importance on prudence $\left(76.6 \%\right.$ vs $\left.68.5 \%, \chi^{2}=5.71, p<.05\right)$ and honesty $\left(76 \%\right.$ vs $66.5 \%, \chi^{2}=7.64$, $p<.01)$. This result indicates that female participants consider having future-oriented objectives at the expense of short-term objectives and consistency between values and behaviors as more important for achieving goals than male participants.

In terms of age, differences in the strength of honesty (Kruskal $H=10.91, p<.05$ ) were found. In relation to the achievement of goals, consistency between values and behaviors was more important for older people 
(age $>55$ years) and for intermediate age (25-45) than for younger people.

CHARACTER STRENGTHS FOR ENRICHING RELATIONSHIPS WITH OTHERS

The major character strengths for developing positive relationships with others included honesty and gratitude (90th percentile $=75.25$ ). This result indicates that having a consistency between values and behavior and feeling and expressing gratitude were the key strengths of character for enriching positive relations with others. Other character strengths commonly viewed as important among participants were social intelligence, humor, love, citizenship, fairness, and kindness ( 75 th percentile $=72.60)$. These results suggest that the ability to reason with emotional information about oneself or others; a positive mood; the desire for contact with others; the preference for collective over individual interests; the ability to make fair judgments; and a community-oriented mindset were considered highly important for developing healthy relationships with others.

In a second step, individual differences according to gender and age were analyzed. Differences were found by gender, in which women, compared with men, emphasized the role of gratitude $(81.7 \%$ vs $69.6 \%$, $\left.\chi^{2}=13.44, p<.01\right)$, love $(82 \%$ vs $66.5 \%$, $\left.\chi^{2}=21.42, p<.01\right)$, citizenship $(77.2 \%$ vs $\left.68.2 \%, \chi^{2}=7.03, p<.01\right)$, fairness $(77.5 \%$ vs $\left.67.9 \%, \chi^{2}=7.97, p<.01\right)$, and kindness $\left(77.5 \%\right.$ vs $\left.67.9 \%, \chi^{2}=7.97, p<.01\right)$. This result indicates that women, compared to men, considered interpersonal relationships as highly dependent on feeling grateful, showing sensitivity towards others, considering social goals over personal desires, the ability to make fair judgments and solidarity towards others.

In terms of differences by age, differences in the strength of humor $(H$ Kruskal $=9.23$, $p<.05)$ were found. This finding indicates that a serene and cheerful view of life and an optimistic mood, even through adversity, were more important for younger than older individuals.
CHARACTER STRENGTHS FOR WORKING WELL WITH OTHERS

The analysis of the results indicates that the major strengths of character for positive work relationships with others are citizenship and fairness (90th percentile $=76.20$ ). These findings show that the ability to be a good co-worker with a strong sense of duty, especially to the work-team; and fairness and impartiality, especially in social relationships, were the key character strengths to working well with others. Other character strengths that were collectively viewed as important are social intelligence, honesty, open-mindedness, and humility (75th percentile $=70.50)$. This result indicates that the ability to reason with emotional information about oneself or others; the consistency between values and behavior; the ability to change one's beliefs based on information from the environment; and modesty, especially in relation to others, were traits considered as highly important to work with other people.

In a second step, individual differences based on gender and age were analyzed. Differences were found by gender, in which women compared to men favored the character strengths of fairness $(80.7 \%$ vs $71.9 \%$, $\left.\chi^{2}=7.43, p<.01\right)$ and humility $(74.3 \%$ vs $\left.67 \%, \chi^{2}=4.30, p<.05\right)$. This result indicates that women considered that being unbiased and modest were highly important positive traits when working with others. No age differences were found for any of the character strengths of the VIA classification.

\section{CHARACTER STRENGTHS FOR CONTRIBUTING TO A BETTER COUNTRY}

The analysis of the results indicates that the major strengths of character for contributing to a better country are fairness and honesty (90th percentile $=77.55$ ). This finding suggests that the ability to make fair decisions and the consistency between one's personal values and behavior are the key character strengths for contributing to a better country or society. 
Other character strengths viewed as important included citizenship, bravery, social intelligence, kindness, and persistence (75th percentile $=72.05)$. In essence, the defense of collective over individual interests; the decision to voluntary act in potentially risky situations; the ability to reason with emotional information about others; the appreciation of solidarity; and the commitment to efforts despite difficulties were viewed as important in forming a better society.

It was also investigated whether individual differences exist according to gender and age. Women were more likely than men to emphasize the character strengths of fairness $\left(86.7 \%\right.$ vs $\left.77.4 \%, \chi^{2}=10.08, p<.01\right)$ and kindness $\left(76.3 \%\right.$ vs $68.2 \%, \chi^{2}=5.66$, $p<.01)$. This result indicates that women were more likely than men to view impartiality and solidarity with others as important positive traits for contributing to a better country.

In addition, differences according to age were noted regarding bravery (Kruskal $H=10.07, p<.05$ ) and persistence (Kruskal $H=11.31, p<.05)$. These findings suggest that individuals aged 25 to 35 years, compared to other age groups, value dedication besides fears or obstacles and the ability to face risky situations as important factors in contributing to a better country.

IMPORTANCE OF CHARACTER STRENGTHS FOR LIFE FULFILLMENT

Finally, the average percentages of high support to character strengths for each area of life fulfillment were calculated (see Table 2). In general terms, all character strengths of the VIA classification were considered important for each of the five areas (62.35 Total Mean, $S D=13.69)$. No individual differences according to the considered areas were found $[F(4,120)=1.55, \mathrm{~ns}]$.

\section{Discussion}

The main finding of the current study is that lay-people consider the strengths of character from the VIA classification as important elements for life fulfillment. Most participants in this study showed a high degree of endorsement (60 to 70\%) to each of the character strengths of the VIA classification for all the areas of a fulfilling life, i.e., achieving personal well-being, accomplishing life goals, enriching personal relationships, working well with others and contributing to a better country. According to the data of this study, it can be concluded that from the point of view of lay-people, character strengths are not only fundamental to feel good but also to function well both in relation to themselves and to the world (Huppert \& So, 2009, 2013). In sum, assuming ordinary people's perspective, a fulfilling life cannot be achieved if personal strengths are not used.

The results from the present research extend the findings of a previous study conducted by Biswas-Diener (2006) who, applying a similar methodology, found that character strengths were important and desirable for different cultural groups. The results presented here not only reinforce Biswas-Diener's conclusions, by including a different cultural group -Latin-American populations that have often been ignored in the study of character strengths (Castro Solano, 2014)- but also extend those findings by showing that from lay-people's point of view character strengths are not only morally and socially desirable but also fundamental to achieve personal well-being and positive functioning.

The role of personal beliefs about what is needed to achieve a fulfilling life, from the point of view of ordinary people rather than more objective measures (e.g., assessment of perceived well-being) is emphasized in this work. Psychology has widely noted how layconceptions or naive assumptions guide the way how the information is processed; the world is understood; and how they influence the way that others are perceived (Kelly, 1955; Heider, 1958). More recently, cognitive and social psychologists highlighted the influence of these assumptions on the actual human behavior (e.g., Carey \& Smith, 1993; Dweck, 
Chiu, \& Hong, 1995; Dweck \& Leggett, 1988; Medin, 1989).

It is important to note that honesty appears an important personal resource for the five areas of life fulfillment considered in this study. The participants deemed important to be morally honest and consistent with one-self. These findings are in line with the result from a previous study (Castro Solano \& Cosentino, 2015) which analyzed, by a free-listing procedure, the intersection between laypersons' naturalistic ideas about positive traits and the character strengths classification proposed by Peterson and Seligman (2004). That research found that the character strength honesty has the higher frequency of admiration reported by ordinary people, along with other character strengths of the virtue courage such as persistence and bravery (Castro Solano \& Cosentino, 2015). In sum, for laypeople, honesty is not only one of the most admired character strengths but also one of the vehicles for a fulfilling life.

When character strengths were grouped into the six virtues of the classification proposed by Peterson and Seligman (2004), it was observed that the character strengths considered as more important (above the 90th percentile) belong mainly to the virtues of courage and justice. Courage means having the willingness to achieve virtuous goals even when confronting obstacles from the environment or facing serious risks (Peterson \& Seligman, 2004). These results may be reinterpreted under the light of Schwartz's (2001) theory of values. According to Schwartz, values are desirable transsituational goals that serve as guiding prin- ciples in people's lives. In our study, it was found that participants emphasize for most areas that contribute to life fulfillment, those strengths more closely related to the values of self-enhancement (e.g., achievement) and openness to change (e.g., self-direction). This finding highlights the importance given to individual interests and the independence of actions. Similar results were found in a study that explored the profile of value in a large and national-wide sample of Argentinean general population, which showed that self-enhancement was one of the most highly deemed values (Zubieta, Fernández \& Sosa, 2012).

Two strengths of character corresponding to the virtue justice, citizenship and fairness, were highlighted by the participants. The virtue justice is associated with aspects that promote a fair life and the belief that rewards are distributed based on people's contributions or the merit that have or deserve (Peterson \& Seligman, 2004). These results are in line with the findings drawn from Lerner's (1965, 1998) theory of a just world, which was applied in a sample with similar socio-demographic characteristics (Zubieta \& Barreiro, 2012). This model suggests that the world is a fair place and people have what they deserve. Although this belief is a cognitive bias, its importance has been highlighted to confront disturbing or threatening events faced by several countries (Furnham, 2003). When assessing these types of beliefs or biases, the study conducted in Argentina showed that people with higher level of education and greater cultural capital believed that justice prevails and, consequently, everyone gets what deserves (Zubieta \& Barreiro, 2012). According to these research and the results of the present study, people highly value justice as a desirable goal to pursue.

Strengths of character appeared as important elements also for contributing to a better country. In this regard, following Keyes' conception of social well-being, it was considered that broader social issues were an important aspect of life fulfillment. Socially healthier individuals should perceive themselves as social resources; should care for and feel safe in their communities; and should lead coherent personal lives (Keyes, $2002,2007)$. In this sense, fairness and honesty were the most important character strengths; these are aspects socially attached to the concept of social well-being. Overall, being fair in making judgments and having a civic consciousness, together with integrity in actions, were important features in the functioning of society.

Regarding gender differences, results consistently showed that women placed 
more importance on character strengths than men. This result is consistent with some studies showing that women generally score more highly on character strengths, and also obtain higher self-reported levels than men (Cosentino, 2011, 2014; Linley et al., 2007; Park, Peterson, \& Seligman, 2006).

In sum, from people's point of view, character strengths are important to achieve life fulfillment, and, particularly, those strengths related to moral integrity and coherence between feelings and action (e.g., honesty) are relevant. The intervention that focuses on strengths has been one of the most empirically validated positive interventions (BiswasDiener, Kashdan \& Minhas, 2011; Seligman, Steen, Park \& Peterson, 2005; Sin \& Lyubomirsky, 2009). However, most research has been conducted with English-speaking populations, and research with Latin American samples is scarce (Castro Solano, 2014). These results should be taken into account when designing psychological interventions culturally adjusted for a particular group.

\section{LIMITATIONS}

This study has some limitations. Firstly, it should be noted that character strengths were assessed with a self-report procedure rather than by an objective measure as is commonly done in the area (e.g., McGrath, 2015; Park et al., 2004). Although this study is in line with previous studies that suggest that the use of character strengths is largely associated with psychological well-being (Gander, Proyer, Ruch, \& Wyss, 2013; Proctor, Maltby, \& Alex, 2011), this work as well as the previous ones, explore implicit ideas rather than objective assessment of the strengths of character. However, as previously discussed, the role of these implicit assumptions in the actual human behavior is highlighted.

Regarding the instrument used, it should be noted that this was not a test or a scale, but a survey that tried to gather in an objective manner participants' point of view. The definitions provided by the authors of the original classification (Peterson \& Seligman, 2004) were used to operationalize each character strength. As response were in a Likertscale format and responses were analyzed at item-level (that is, one response $=1$ item), positive asymmetry of scores was expected given the level of responses' social desirability that is usually found in the literature on character strengths (Dahlsgaard et al., 2005; Park et al., 2006). Consequently, simple statistics at frequencies level was used to more accurately reflect what respondents thought. For this particular case, running more complex statistics (e.g., parametric), would violate basic statistical assumptions and would not have been appropriate for the purposes of study and assessment techniques used, which were based on the survey methodology.

\section{Final CONCLUSION}

Overall, positive psychology applies generic and nonspecific interventions that pay little attention to individuals' and participants' point of view. Thus, knowing people's implicit ideas and beliefs in regards to that character strengths that contribute most to life fulfillment will allow generating more accurate and culturally adjusted interventions to the particular group in question. This knowledge would not only work as a key motivational element but would also reinforce the effect of the intervention.

Based on the findings of this research, future studies experimentally compare the effectiveness of generic interventions on character strengths versus interventions focused on those strengths that the group under study deems important. Especially, it is necessary to study Latino populations in which the efficacy of these interventions has not been tested yet and little research has been conducted with this particular group in relation to this topic. 
TABLE 1

Percentage of Responses Indicating agreement With the Statement that CHARACTER StRengthS FAVOR LIFE FULFILLMENT, SEPARATELY PRESENTED UNDER EACH VIRTUE

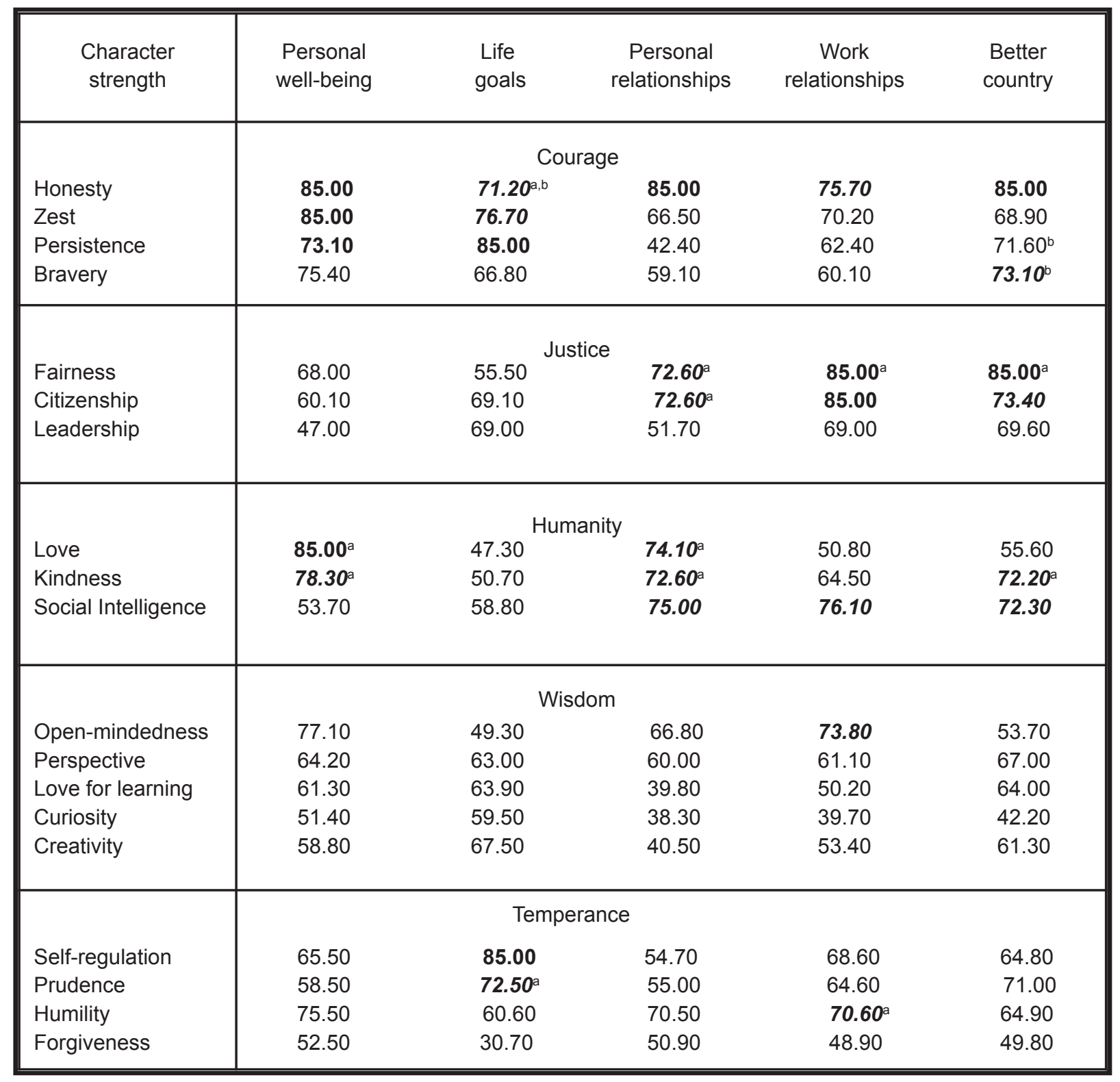

Note:

Appreciation: appreciation of beauty and excellence.

Bold: character strengths located in the top decile.

Bold \& italic: character strengths located in the first quartile.

${ }^{a}$ Gender differences.

${ }^{\mathrm{b}}$ Age differences. 


\section{TABLE 1 (CONTINUATION)}

PERCENTAGE OF RESPONSES INDICATING AGREEMENT WITH THE STATEMENT THAT CHARACTER STRENGTHS FAVOR LIFE FULFILLMENT, SEPARATELY PRESENTED UNDER EACH VIRTUE

\begin{tabular}{|c|c|c|c|c|c|}
\hline $\begin{array}{l}\text { Character } \\
\text { strength }\end{array}$ & $\begin{array}{c}\text { Personal } \\
\text { well-being }\end{array}$ & $\begin{array}{l}\text { Life } \\
\text { goals }\end{array}$ & $\begin{array}{l}\text { Personal } \\
\text { relationships }\end{array}$ & $\begin{array}{c}\text { Work } \\
\text { relationships }\end{array}$ & $\begin{array}{l}\text { Better } \\
\text { country }\end{array}$ \\
\hline & \multicolumn{5}{|c|}{ Transcendence } \\
\hline Gratitude & $78.30^{a}$ & 50.40 & $85.00^{a}$ & 69.70 & 59.80 \\
\hline Hope & $82.70^{a}$ & 76.10 & 57.40 & 60.00 & 66.20 \\
\hline Humor & $81.40^{b}$ & 53.10 & $74.70^{b}$ & 69.30 & 49.80 \\
\hline Spirituality & 61.40 & 42.90 & 37.30 & 34.60 & 40.20 \\
\hline Appreciation & 53.30 & 29.20 & 31.30 & 24.90 & 31.30 \\
\hline
\end{tabular}

Note:

Appreciation: appreciation of beauty and excellence.

Bold: character strengths located in the top decile.

Bold \& italic: character strengths located in the first quartile.

a Gender differences.

${ }^{\mathrm{b}}$ Age differences.

TABLE 2

MEAN AND STANDARD DEVIATION OF PERCENTAGES OF ENDORSEMENT TO THE CHARACTER STRENGTHS FOR THE FIVE AREAS STUDIED

\begin{tabular}{|l|cc|}
\hline \multicolumn{1}{|c|}{ Areas } & $M$ & $S D$ \\
\hline Personal well-being & 68.11 & 12.34 \\
Better country & 62.76 & 12.85 \\
Work relationships & 61.38 & 13.99 \\
Personal relationships & 60.45 & 14.58 \\
Life Goals & 59.05 & 14.71 \\
\hline
\end{tabular}




\section{References}

American Psychiatric Association. (2013). Diagnostic and statistical manual of mental disorders (5th ed.). Washington, DC: Author.

Barreiro, A., Etchezahar, E., \& Prado-Gasco, V. (2014). Creencia global en un mundo justo: validación de la escala de Lipkus en estudiantes universitarios de la Ciudad de Buenos Aires [Global belief in a just world: Validation of the Lipkus Scale in university students from city of Buenos Aires]. Interdisciplinaria, 31(1), 57-71. http://dx.doi.org/10.16888/interd.2014.31.1.4

Baumeister, R.F., Vohs, K.D., Aaker J.L., \& Garbinsky, E.N. (2013). Some key differences between a happy life and a meaningful life. The Journal of Positive Psychology, 8, 505-516.

Biswas-Diener, R. (2006). From the equator to the North Pole: A study of character strengths. Journal of Happiness Studies, 7(3), 293-310. http://dx.doi.org/10.1007/s10902-005-3646-8

Biswas-Diener, R., Kashdan, T. B., \& Minhas, G. (2011). A dynamic approach to psychological strength development and intervention. The Journal of Positive Psychology, 6(2), 106-118. http://dx.doi.org/10.1080/17439760.2010.545 4 29

Carey, S. \& Smith, C. (1993). On understanding the nature of scientific knowledge. Educational Psychologist, 28, 235-251.

Castro Solano, A. (2014). Positive psychology in Latin American countries. Dordrecht: Springer Netherlands. http://dx.doi.org/10.1007/978-94017-9035-2

Castro Solano, A. \& Cosentino, A.C. (2015). The bridge between naturalistic and theoretical views on character strengths: A combined emic and etic approach. Manuscript submitted for publication.

Cosentino, A.C. (2011). Fortalezas del carácter en militares argentinos [Character strengths in Argentinean soldiers]. Unpublished doctoral thesis. Universidad de Palermo. Buenos Aires, Argentina.

Cosentino, A.C. (2014). Character strengths: Measurement and studies in Argentina with military and general population samples. In A. Castro Solano (Ed.), Positive Psychology in Latin America (pp. 111-127). Dordrecht: Springer Netherlands. http://dx.doi.org/10.10 07/978-94-0179035-2_6.

Cosentino, A.C. \& Solano, A.C. (2012). Character strengths: A study of Argentinean Soldiers. The Spanish Journal of Psychology, 15(01), 199215. http://dx.doi.org/10.5209/rev_ SJOP.20 12.v15.n1.37310

Csikszentmihalyi, M. (1990). Flow: The psychology of optimal experience. New York: Harper and Row.

Dahlsgaard, K., Peterson, C., \& Seligman, M.E.P. (2005). Shared virtue: The convergence of valued human strengths across culture and history. Review of General Psychology, 9, 203213. http://dx.doi.org/10.1037/1089-2680.9.3. 203

Diener, E.D., Emmons, R.A., Larsen, R.J., \& Griffin, S. (1985). The Satisfaction with Life Scale. Journal of Personality Assessment, 49 (1), 71-75.

Dweck, C.S. \& Leggett, E.L. (1988). A socialcognitive approach to motivation and persona $1-$ ity. Psychological Review, 95, 256-273.

Dweck, C.S., Chiu, C.Y., \& Hong, Y.Y. (1995). Implicit theories and their role in judgments and reactions: A word from two perspectives. Psychological Inquiry, 6(4), 267-285.

Forgeard, M.J.C., Jayawickreme, E., Kern, M.L., \& Seligman, M.E.P. (2011). Doing the right thing: Measuring well-being for public policy. International Journal of Well-being, 1(1), 79106. http://dx.doi.org/10.5502/ijw.v1i1.15

Furnham, A. (2003). Belief in a just world: Research progress over the past decade. Personality and Individual Differences, 34(5), 795817.

Gander, F., Proyer, R.T., Ruch, W., \& Wyss, T. (2013). Strength-based positive interventions: Further evidence for their potential in enhancing well-being and alleviating depression. Journal of Happiness Studies, 14(4), 12411259. http://dx.doi.org/10.1007/s10902-012-9 380-0 
Huppert, F.A. \& So, T. (2009, July). What percentage of people in Europe are flourishing and what characterizes them? Briefing document for the OECD/ISQOLS Meeting "Measuring subjective well-being: An opportunity for NSOs?". Florence, Italy.

Huppert, F.A. \& So, T.T. (2013). Flourishing across Europe: Application of a new conceptual framework for defining well-being. Social Indicators Research, 110(3), 837-861. http://dx.doi.org/ 10.1007/s11205-011-9966-7

Huta, V. \& Ryan, R.M. (2010). Pursuing pleasure or virtue: The differential and overlapping wellbeing benefits of hedonic and eudaimonic motives. Journal of Happiness Studies, 11, 735762.

Huta, V. \& Waterman, A.S. (2014). Eudamonia and its distinction from Hedonia: Developing a classification and terminology for understanding conceptual and operational definitions. Journal of Happiness Studies, 15(6), 1425-1456. http:// dx.doi.org/10.1007/s10902-013-9485-0

Kelly, G.A. (1955). The psychology of personal constructs. New York: Norton.

Keyes, C.L.M. (2002). The mental health continuum: From languishing to flourishing in life. Journal of Health and Social Behavior, 43, 207222.

Keyes, C.L.M. (2007). Promoting and protecting mental health as flourishing: A complementary strategy for improving national mental health. American Psychologist, 62, 95-108. http://dx. doi.org/10.1037/0003-066X.62.2.95

King, L.A. \& Hicks, J.A. (2009). Detecting and constructing meaning in life. The Journal of Positive Psychology, 4, 317-330.

Lerner, M.J. (1965) Evaluation of performance as a function of performer's reward and attractiveness. Journal of Personality and Social Psychology, 1(4), 355-360.

Lerner, M.J. (1998). The two forms of belief in a just world: Some thoughts on why and how people care about justice. In L. Montada \& M. J. Lerner (Eds.), Responses to victimizations and belier in a just world (pp. 247-270). New York: Plenum.
Linley, P.A., Maltby, J., Wood, A.M., Joseph, S., Harrington, S., Peterson, C., et al. (2007). Character strengths in the United Kingdom: The VIA Inventory of Strengths. Personality and Individual Differences, 43(2), 341-351. http://dx.doi.org/ 10.1016/j.paid.2006.12.004

Lounsbury, J.W., Fisher, L.A., Levy, J.J., \& Welsh, D.P. (2009). An investigation of character strengths in relation to the academic success of college students. Individual Differences Research, 7(1), 52-69.

Macdonald, C., Bore, M., \& Munro, D. (2008). Values in action scale and the Big 5: An empirical indication of structure. Journal of Research in Personality, 42(4), 787-799. http://dx.doi. org/10.1016/j.jrp.2007.10.003

McGrath, R.E. (2015). Measurement Invariance in Translations of the VIA Inventory of Strengths. European Journal of Psychological Assessment. On-line Advanced publication. http://dx. doi.org/10.1027/1015-5759/a000248

Medin, D.L. (1989). Concepts and conceptual structure. American Psychologist, 44, 14691481.

Park, N. (2004). Character strengths and positive youth development. Annals of the American Academy of Political and Social Science, 591, 40-54. http://dx.doi.org/10.1177/00027162032 60079

Park, N. \& Peterson, C. (2009). Strengths of character in schools. In R. Gilman, E.S. Huebner, \& M.J. Furlong (Eds.), Handbook of positive psychology in schools (pp. 65-76). New York, NY, US: Routledge / Taylor \& Francis Group.

Park, N., Peterson, C., \& Seligman, M.E.P. (2004). Strengths of character and well-being. Journal of Social and Clinical Psychology, 23(5), 603619. http://dx.doi.org/10.1521/jscp.23.5.603. 50748

Park, N., Peterson, C., \& Seligman, M.E.P. (2006). Character strengths in fifty-four nations and the fifty US states. The Journal of Positive Psychology, 1(3), 118-129. http://dx.doi.org/10.10 80/17439760600619567

Pavot, W. \& Diener, E. (2008). The satisfaction with life scale and the emerging construct of 
life satisfaction. The Journal of Positive Psychology, 3(2), 137-152.

Peterson, C., Park, N., \& Seligman, M.E.P. (2006). Greater strengths of character and recovery from illness. The Journal of Positive Psychology, 1(1), 17-26. http://dx.doi.org/10.1080/174 39760500372739

Peterson, C., Park, N., Pole, N., D'Andrea, W., \& Seligman, M.E. (2008). Strengths of character and posttraumatic growth. Journal of Traumatic Stress, 21(2), 214-217. http://dx.doi.org/10.10 02/jts. 20332.

Peterson, C. \& Seligman, M.E.P. (2004). Character strengths and virtues: A handbook and classification. Washington, DC: APA Press and Oxford University Press.

Proctor, C., Maltby, J., \& Alex, P. (2011). Strengths use as a predictor of well-being and healthrelated quality of life. Journal of Happiness Studies, 12(1), 153-169. http://dx.doi.org/10.10 07/s10902-009-9181-2

Proyer, R.T., Gander, F., Wyss, T., \& Ruch, W. (2011). The relation of character strengths to past, present, and future life satisfaction among German-speaking women. Applied Psychology: Health and Well-Being, 3(3), 370-384.

Proyer, R.T., Ruch, W., \& Buschor, C. (2013). Testing strengths-based interventions: A preliminary study on the effectiveness of a program targeting curiosity, gratitude, hope, humor, and zest for enhancing life satisfaction. Journal of Happiness Studies, 14(1), 275-292.

Ruch, W., Huber, A., Beermann, U., \& Proyer, R.T. (2007). Character strengths as predictors of the "good life" in Austria, Germany and Switzerland. In Romanian Academy "George Barit" Institute of History, Department of Social Research (Ed.), Studies and researches in social sciences, Vol. 16 (pp. 123-131). Cluj-Napoca, Romania: Argonaut Press.

Ryan, R.M. \& Deci, E.L. (2000). Self-determination theory and the facilitation of intrinsic motivation, social development, and well-being. American Psychologist, 55, 68-78.

Ryff, C.D. (1989). Happiness is everything, or is it? Explorations on the meaning of psycholo- gical well-being. Journal of Personality and Social Psychology, 57(6), 1069-1081. http://dx. doi.org/10.1037/0022-3514.57.6.1069.

Ryff, C.D. (2014). Psychological well-being revisited: Advances in the science and practice of eudaimonia. Psychotherapy and Psychosomatics, 83(1), 10-28. http://dx.doi.org/10.1159/000 353263

Ryff, C.D. \& Singer, B. (1998). The contours of positive human health. Psychological Inquiry, 9(1), 1-28. http://dx.doi.org/10.1207/s1532796 5pli0901_1.

Schwartz, S.H. (2001). ¿Existen aspectos universales en la estructura y contenido de los valores humanos? [Are there universal aspects in the structure and content of human values?]. In M. Ros \& V. Gouveia (Eds.), Psicología social de los valores humanos (pp. 53-76). Madrid: Biblioteca Nueva.

Seligman, M.E. (2002). Authentic happiness: Using the new positive psychology to realize your potential for lasting fulfillment. New York: Simon and Schuster.

Seligman, M.E. (2011). Flourish: A visionary new understanding of happiness and well-being. New York: Simon and Schuster.

Seligman, M. E., Rashid, T., \& Parks, A. C. (2006). Positive psychotherapy. American Psychologist, 61(8), 774.

Seligman, M.E., Steen, T.A., Park, N., \& Peterson, C. (2005). Positive psychology progress: Empirical validation of interventions. American Psychologist, 60(5), 410.

Sin, N.L. \& Lyubomirsky, S. (2009). Enhancing well-being and alleviating depressive symptoms with positive psychology interventions: A practice-friendly meta-analysis. Journal of Clinical Psychology, 65(5), 467-487.

Steger, M.F., Frazier, P., Oishi, S., \& Kaler, M. (2006). The meaning in life questionnaire: Assessing the presence of and search for meaning in life. Journal of Counseling Psychology, 53, 80-93.

Steger, M.F., Hicks, B.M., Kashdan, T.B., Krueger, R.F., \& Bouchard Jr., T.J. (2007). Genetic and environmental influences on the positive traits 
of the values in action classification, and biometric covariance with normal personality. Journal of Research in Personality, 41(3), 524539. ttp://dx.doi.org/10.1016/j.jrp.2006.06.002. Waterman, A.S. (2008). Reconsidering happiness: A eudaimonist's perspective. The Journal of Positive Psychology, 3(4), 234-252. http://dx. doi.org/10.1080/1743976080230 3002.

Weber, M., Ruch, W., Littman-Ovadia, H., Lavy, S., \& Gai, O. (2013). Relationships among higher-order strengths factors, subjective wellbeing, and general self-efficacy - The case of Israeli adolescents. Personality and Individual Differences, 55, 322-327.
Wong, P.T.P. (2011). Positive psychology 2.0: Towards a balanced interactive model of the good life. Canadian Psychology, 52(2), 69-81. http://dx.doi.org/10.1037/a0022511

Zubieta, E. \& Barreiro, A. (2012). Percepción social y creencia en el mundo justo. Un estudio con estudiantes argentinos [Social perception and belief in just world. A study of Argentine students]. Revista de Psicología, 24(2), 175196.

Zubieta, E., Fernández, O., \& Sosa, F. (2012). Bienestar, valores y variables asociadas [Welfare, values and variables associated]. Boletín de Psicología, 106, 7-27.

Consejo Nacional de Investigaciones Cientificas y Técnicas (CONICET)

Universidad de Palermo

Ciudad Autónoma de Buenos Aires República Argentina

Received: March 30, 2015

Accepted: January 25, 2016 